\title{
EDITORIAL Reformulação Curricular dos Cursos de Física
}

A educação básica brasileira foi, recentemente, sacudida por pedidos de mudanças na forma de uma "enxurrada" de novas siglas e palavras de ordem, como LDB, PCNs, Ensino por competências, entre outras. Neste contexto de mudanças, algumas se fizeram sentir mais diretamente na escola. O antigo segundo grau foi substituído pelo Ensino Médio, assim como o primeiro grau transformou-se no Ensino Fundamental. Muito do que era considerado bom ensino foi abruptamente classificado de ensino tradicional, como sinônimo de ensino sem significado para os alunos. A Física em particular, assim como as ciências em geral, foram duramente criticadas por serem formas de conhecimento descoladas da realidade e de interesse duvidoso.

Este choque que hoje atinge professores e dirigentes escolares é conseqüência de uma onda produzida seis anos atrás e que se propõe a ser muito mais do que uma mudança de siglas. Em 1996 tivemos a aprovação da nova lei de Diretrizes e Bases da Educação (LDB), que embutia uma nova forma de conceber a educação. Junto com ela uma série de medidas governamentais foram produzidas no sentido de modificar o panorama da educação brasileira. A LDB se reveste de caráter legal (pois é uma lei) e determina em linhas gerais os objetivos e funcionamento da educação Básica (Ensino Fundamental e Médio) e Educação Superior. O que hoje vivenciamos nas escolas são as medidas concretas, produzidas a partir deste novo foco gerado pela LBD.

Especificamente na Física, as mudanças se localizaram inicialmente nos objetivos do ensino que produzimos. $\mathrm{O}$ antigo segundo grau, que se revestia de um caráter propedêutico (meio de acesso à Universidade), passou a ter função formativa final para a cidadania. Ou seja, o novo Ensino Médio passa a ser pensado como um fechamento em termos de formação de tudo aquilo de que o cidadão necessita para a boa condução de sua vida. Os PCNs (Parâmetros Curriculares Nacionais) sintetizam e, ao mesmo tempo, sistematizam orientações gerais dos objetivos da educação básica.

Outra conseqüência da LDB foi a recente discussão envolvendo a reformulação dos cursos de licenciatura em geral. Em maio de 2000, o Ministério da Educação (MEC) submeteu ao Conselho Nacional de Educação(CNE) uma "Proposta para as Diretrizes Curriculares Nacionais para a Formação Inicial de Professores da Educação Básica, em nível superior, curso de licenciatura, de graduação plena". Este documento, elaborado por um grupo de trabalho do MEC foi debatido no âmbito do CNE. Em março de 2001, foram realizadas cinco audiências públicas com a participação de entidades representativas de diversos segmentos da sociedade ligadas à área de educação, com o objetivo de receber propostas para subsidiar a avaliação da proposta, visando o Projeto de Resolução que nortearia o funcionamento dos cursos de licenciatura, nos quais se encontram os de Física.

A proposta original propunha mudanças radicais em relação ao que se conhece hoje como cursos de licenciatura, incluindo, por exemplo, a necessidade de estágios curriculares supervisionados a partir do primeiro ano, além de um aumento brutal no número de horas desse estágio.

A Resolução aprovada pelo CNE, em agosto de 2002, pareceu limitar parte dessas mudanças. Resumidamente, as características para os curso de licenciatura passam a ser, no tocante à carga horária, as seguintes:

1- $\quad 400 \mathrm{~h}$ de prática como componente curricular, vivenciadas ao longo do curso;

2- $\quad 400 \mathrm{~h}$ de estágio curricular supervisionado a partir da segunda metade do curso;

3- $\quad 1800 \mathrm{~h}$ de aulas para os conteúdos curriculares de natureza científico-cultural;

4- $\quad 200 \mathrm{~h}$ para outras formas de atividades acadêmico-científico-culturais.

Os detalhes sobre tais medidas encontram-se nos pareceres, CNE/CP009/2001, CNE/CP 21/2001,

CNE/CP27/2001, que podem ser obtidos no site do Conselho Nacional de Educação.

Restam ainda pequenos ajustes a serem feitos, em particular no tocante à harmonização dessa resolução com outra, que regulamenta as diretrizes para os cursos de graduação em Física. Mas o principal das mudanças parece ser as acima expostas. Resta-nos agora adaptar os cursos de licenciatura às novas orientações curriculares.

Maurício Pietrocola

Secretário para Assuntos de Ensino da SBF

\section{RBEF no SciELO}

Com enorme satisfação informamos que a Revista Brasileira de Ensino de Física já se encontra disponível no site SciELO Brasil (www.scielo.br). A fim de agilizar a consulta e a visibilidade individual de cada publicação, além do acesso pela lista de periódicos na SciELO, é possível consultar a revista a partir de sua home page no endereço: http://www.scielo.br/rbef. A SciELO (Scientific Electronic Library Online) é uma biblioteca eletrônica cobrindo uma seleta coleção de periódicos científicos brasileiros.

O Editor 